\title{
CONNECTION APPROACHES BETWEEN TRADITIONAL AND MODERN PHARMACOLOGICAL PROFILE OF SHOREA ROBUSTA GAERTN. F.: A REVIEW
}

\author{
MANISH PAL SINGH ${ }^{1 *}$, RAVI KUMAR ${ }^{1}$ \\ ${ }^{1}$ Department of Pharmacology, Rajiv Academy for Pharmacy, Mathura - 281 001, Uttar Pradesh, India. Email: manish_bn@yahoo.co.in
}

Received: 30 April 2018, Revised and Accepted: 25 May 2018

\begin{abstract}
Shorea robusta is regarded as an important medicine in Ayurveda. S. robusta Gaertn. f. belongs to family Dipterocarpaceae, and traditionally, it is used to treat wounds, ulcers, leprosy, cough, gonorrhea, earache, and headache and many more. The use of different parts of this plant such as leaves, resin, and bark as a medicament for the treatment of various conditions is well documented in literature. It is the rich source of flavonoids, saponins, steroids, tannins, phenols, etc. mainly triterpenoids, which play the prominent role for their therapeutic potential in the drug. These compounds are believed to be responsible for the pharmacological activities of plant extract. The present review clarified the main active ingredients and pharmacological effects of $S$. robusta as a promising plant as a result of effectiveness and safety. Further studies should be carried out this plant to discover the unrevealed part of it which may serve for the welfare of humankind.
\end{abstract}

Keywords: Shorea robusta, Tannins, Phenols, Wound healing, Antidiabetic.

(C) 2018 The Authors. Published by Innovare Academic Sciences Pvt Ltd. This is an open access article under the CC BY license (http://creativecommons. org/licenses/by/4. 0/) DOI: http://dx.doi.org/10.22159/ajpcr.2018.v11i9.26978

\section{INTRODUCTION}

Plants have been an important source of medicine with qualities for thousands of years. Plants are used medicinally in different countries, and they are the source of many potent and powerful drugs. Mainly on traditional remedies such as herbs for their history, they have been used popular folk medicine [1,2]. Shorea robusta is regarded as an important medicine in Ayurveda. S. robusta Gaertn. f. belongs to family Dipterocarpaceae, and traditionally, it is used to treat wounds, ulcers, leprosy, cough, gonorrhea, earache, and headache and many more. Different parts of the plant are traditionally used for the treatment of diverse purpose $[3,4]$. In Ayurveda, the leaves are used as anthelmintic, anti-inflammatory, antinociceptive, hyperlipidemic, antioxidant, and alexiteric. The leaves are used to treat wounds, ulcers, itching, leprosy, gonorrhea, cough, earache, and headache. The powdered stem bark or bark paste is applied to stop bleeding and promote healing of cuts $[5,6]$. In the Unani system of medicine, the resin is used to treat menorrhagia, enlargement of spleen, relieving eye irritations. The resin is used as antimicrobial, analgesic, and antiulcer. Its resin with honey or sugar is given in dysentery and also given in gonorrhea and for weak digestion. The oleoresin exuded from the cut bark has astringent and detergent properties $[7,8]$. The bark is used to treat diabetes, diarrhea, dysentery, wounds, and ulcers. Its bark decoction is used as drops in ear problems. Besides, its fruits are used to treat diarrhea [9-12]. This review was mainly sited the information to highlight the modern and traditional therapeutically pharmacological profile of $S$. robusta plant belonging to family Dipterocarpaceae, which may serve as a source for further studies.

\section{PLANT PROFILE [13-17]}

- Botanical name: S. robusta.

- Family: Dipterocarpaceae.

- Vernacular names: Guggilam, Ashvakarna, Chiraparna, Sal, Sala, Sarja, Sal tree, Common Sal, Indian Dammer, Dhuna, Damar, Jall, Sal, Salwa, and Shal.

- $\quad$ Parts used: Resin, leaves, bark, and fruit (Fig. 1).

- Chemical constituents: Phytochemical screening reveals the presence of flavonoids, saponins, steroids, tannins, phenols, etc., mainly triterpenoids which plays the prominent role for their therapeutic potential in the drug.

\section{Traditional uses of plant}

The resin obtained from the plant is considered as an astringent and a detergent and is used with honey or sugar in dysentery and bleeding piles and also for fumigating the rooms of ill people. It is also given in gonorrhea and for weak digestion. Its bark decoction is used as drops for ear problems and the fruits for diarrhea. India dammar resin Shorea robusta. It exudes from the fissure made in the bark of the tree in the form of a gum resin. It is a useful drug in European pharmacopeia. It consists of two kinds, namely white and red, and it is used for fumigating like frankincense and is soluble in alcohol. Mixed with sulphur, it is used as an ointment for wound source etc. And mixed with wax it, is used as plasters for wounds. It is bitter, pungent and nauseating. Traditional physicians prescribe it for venereal complaints as gonorrhea, gout, etc. Mixed with boiled milk it is a useful remedy in cough, piles, bronchitis, and leucorrhoea. It is capable of absorbing all morbid fluid from the system. The resin is also used on increase in several Hindu households, temples, and sick rooms. The powdered stem bark or bark paste is applied to stop bleeding and promote healing of cuts among the tribal inhabitants of southern Bihar and the Kondhs of southwestern Orissa [18,19].

\section{PHARMACOLOGICAL ACTIVITY}

\section{Wound healing activity}

Khan et al. investigated the wound healing activity of $S$. robusta resin extracts and essential oil in rats. In this study, various extracts of plant resin were incorporated in soft yellow paraffin $(10 \% \mathrm{w} / \mathrm{w})$ and applied once daily on incision and excision wounds of Wistar rats. Framycetin ointment $(1.0 \% \mathrm{w} / \mathrm{w})$ was also applied to the standard group. Authors have been revealed into this study that the extract treatment group wound was 53\% higher than that of control animals. Protein and hydroxyproline contents were higher extract groups (20.8 and $3.5 \% \mathrm{w} / \mathrm{w}$ ) as compared to control group [20], and other investigator also reported wound healing activity of some herbal plants containing flavonoid and phenol phytoconstituents [21-23]. Sahasrabudhe et al. reported the healing of second-degree burns by resin extract of S. robusta (SRE) using first-degree, third-degree burns and electrical burn models. Raal ointment found to be a suitable alternative to silver sulfadiazine cream for the treatment of second-degree burns [24]. Mukherjee et al. have been reported that the topical application of the extract of young leaves of $S$. robusta and its isolated compounds such as 


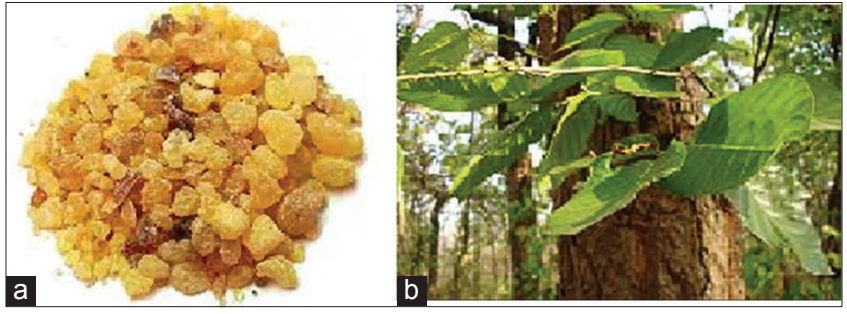

Fig. 1: Morphology of Shorea robusta (a) resin of plant and (b) whole plant of $S$. robusta

ursolic acid and bergenin promote wound healing activity in excision incision and dead space wound models in rats, probably by inhibiting or modulating some mediators and inflammatory cytokines such as TNF- $\alpha$ and PGE2. The histology examination of this study has been revealed that the promoting of tissue collagen content like hydroxyproline more founded in the treatment group of animals [25] and some other investigation were claimed to beneficial wound healing activity of these plant phytoconstituents [26-28].

Wani et al. carried out the study to investigate the wound healing activity of ethanolic SRE resin. The study of this research was used incision and excision wound healing animal model. Investigators were reported that the ethanolic SRE (10 and $30 \% \mathrm{w} / \mathrm{w}$ applied locally in excised and incised wounds) produced a dose-dependent acceleration in wound contraction and increased hydroxyproline content and tensile strength of wounds in rats $[29,30]$. Datta et al. have been prepared five topical formulations using cow ghee, flax seed oil, Phyllanthus emblica fruits, $S$. robusta resin, and Yashada bhasma as their study materials. Investigators have been reported that the group treated with the formulations containing Y. bhasma along with S. robusta resin and flax seed oil showed significantly better wound contraction $(\mathrm{p}<0.01)$, higher collagen content $(\mathrm{p}<0.05)$, and better skin breaking strength $(\mathrm{p}<0.01)$ as compared to control group [31]. Wound healing effect of herbal plant is beneficial for over the synthetic product [32-36].

\section{Antimicrobial activity}

Vashisht et al. have reported the antioxidant and antibacterial properties of the methanolic extract of the resin of S. robusta. The methanol extract of the resin was tested for antioxidant activity using scavenging activity of 1,1- diphenyl-2-picrylhydrazil (DPPH) radical method, reducing power by $\mathrm{FeCl}_{3}$ and antibacterial activity against Gram-positive and Gram-negative bacteria using disc diffusion method. The study has been revealed that the half inhibition concentration of resin extracts of $S$. robusta and ascorbic acid was $35.60 \mu \mathrm{g} / \mathrm{ml}$ and $31.91 \mu \mathrm{g} / \mathrm{ml}$, respectively. The resin extract exhibits a significant dose-dependent inhibition of DPPH activity. Investigators have been also proved of $S$. robusta antibacterial activity which was observed against Gram-positive and Gram-negative bacteria in dose dependent manner [37]. Banerjee et al. carried out the study that focuses on phytochemical analysis and antimicrobial effects of lal dhuna, a natural resin secreted from $S$. robusta (Sal). The methanolic and ethanolic extracts of lal dhuna were prepared by distillation method. Antimicrobial activity was tested in Escherichia coli, Salmonella typhi, Pseudomonas sp., and Staphylococcus aureus culture. This study has been concluded that the potent antimicrobial consisting has both the extracts through procuring zone of inhibition (ZOI) on culture media which was nearly equivalent to the antibiotics applied [38]. Adlakha et $a l$. have been reported the antimicrobial activity of $S$. robusta by agar well diffusion method against some pathogenic bacteria. The extract possesses significant antibacterial activity [39].

Murthy et al. reported the antimicrobial activity of the aqueous, methanol, ethanol, petroleum, and benzene extract of oleoresin of $S$. robusta by disc diffusion method. Aqueous extracts of $S$. robusta exhibit significant activity against Bacillus coagulans, E. coli, and Bacillus cereus, moderate inhibition on $S$. typhi and Bacillus subtilis, and less activity against Proteus vulgaris and Pseudomonas fluorescence. However, ethanolic extracts also exhibited significant activity against $S$. aureus, S. epidermidis, and E. coli and moderate inhibition on Candida albicans and $B$. coagulans. Investigators have been reported that the methanol extract has shown more significant activity [40]. Duddukuri et al. reported the antimicrobial activity of aqueous extract of floral parts of the $S$. robusta against the Gram-positive bacteria, namley $S$. aureus and B. subtilis, and Gram-negative bacteria, namely Klebsiella pneumoniae and Serratia marcescens by well diffusion method. Aqueous extract of the plant has shown a significant inhibitory activity on different bacterial species tested against penicillin as standard antibacterial agent [41]. Gaurea et al. also investigated the antimicrobial effect of resin of some herbal plants. They have been reported the resins of Boswellia serrata, C. mukul, and Gardenia resinifera exhibiting activity against Gram-positive bacteria, comparable to standard antibiotic amoxicillin, but they did not have the activity against Gram-negative bacteria. In this investigation, the maximum ZOI was found against $B$. cereus by B. serrata resin sample prepared in ethanol [42]. Some other investigation have been also confirmed the antimicrobial activity of resin containing of plant constituents [43-46].

\section{Antiulcer activity}

Vimala et al. reported the antiulcerogenic activity of $S$. robusta. The extract of $S$. robusta was administered at the doses of 150 and $300 \mathrm{mg} / \mathrm{kg}$ orally in rats against ethanol and pylorus ligation-induced gastric ulcer. The extract significantly increases the gastroprotective activity as compared to control [47]. Santoshkumar et al. investigated the antiulcer activity of $S$. robusta Gaertn. f. Investigators have concluded that the treatment group has more antiulcerogenic effects when compared to the reference drug omeprazole. The study results have been suggested that $S$. robusta resin possess significant gastroprotective activity [48]. Other scientific investigations have been proved that the plant contains polyphenols and flavonoids revealed possess the protective effective as gastric ulcer treatment [49-53].

\section{Antioxidant activity}

Mathavi et al. reported that the ethanolic SRE leaves have shown in vitro antioxidant activity. The ethanolic extract was screened for in vitro antioxidant activity by oxygen radical scavenging such as DPPH, total antioxidant assay, superoxide metal chelation and iron reducing power activity at different concentration throughout the studies leaves extract showed marked antioxidant activity. The antioxidant activity was found to be concentration dependent and may be attributed to the presence of bioflavonoids content in the leaves of S. robusta [54]. Ramasamy et al. evaluated the antioxidant activity of the acetone and methanol extracts of the stem bark of the plant, Shorea roxburghii. In this study, the total phenolic content and antioxidant activity of the extracts were determined by $\mathrm{DPPH}$, radical scavenging, ferric ion reducing power, hydroxyl radical, and ABTS. Both acetone and methanol extracts of $S$. roxburghii stem bark were found to be a potent antioxidant. The current study provides a scientific support for the high antioxidant activity of this plant, and thus, it may find potential applications in the treatment of the diseases caused by free radical [55]. Several studies confirmed that the plant containing flavonoids, phenols, and polyphenols are responsible for free radical scavenging activity of herbal drugs and it is may be responsible for antioxidant activity of this plant resin [56-60].

\section{Immunomodulatory activity}

Adlakha et al. have been reported the antinociceptive, antiobesity, and immunomodulatory activity of $S$. robusta bark using formalininduced paw licking model. The bark extract administered rat models at $300 \mathrm{mg} / \mathrm{kg} /$ day intraperitoneal route. The study results have been shown a significant effect in stimulating immunomodulatory response and significant antinociceptive response [39]. Kalaiselvan et al. reported the immunomodulatory activities of $S$. robusta. Sheep red blood cells $(5 \times 109$ cells $/ \mathrm{ml})$ were used for immunizing the animals that belong to immunized groups. This study was performed with a set of immunomodulation such as the humoral antibody response (hemagglutination antibody titers and immunoglobulins), cell-mediated immune response (delayed type hypersensitivity and phagocytosis), 
nitroblue tetrazolium reduction test, total lymphocyte count, and DC. Investigators have been concluded that the Shorea robusta bark extract administrated rat models at $300 \mathrm{mg} / \mathrm{kg}$ per day, i.p should significant important in stimulating immunomodulatory response, thus Shorea robusta bark is an effective natural health product for in modulating immune system [61]. Several scientific studies have well documented for immunomodulatory activity of polyphenols and flavonoids containing plant [62-66].

\section{Anti-inflammatory and analgesic activity}

Nainwal et al. investigated the in vitro anti-inflammatory activity of leaf SRE using heat-induced hemolytic method. The SRE contains good amount of tannins, flavonoids, and saponins; these possess good activity against inflammation [67]. Debprasad et al. have been reported the antiinflammatory and analgesic activities and the possible mechanism of action of tender leaf extracts of $S$. robusta. Analgesic was induced by the writhing and tail flick methods, while the anti-inflammatory activity was evaluated in carrageenan- and dextran-induced paw edema and cotton pellet-induced granuloma model. The authors promoted have results revealed that both aqueous and methanol extract $(400 \mathrm{mg} / \mathrm{kg}$ ) caused significant reduction of writhing and tail flick, paw edema, granuloma tissue formation $(\mathrm{p}<0.01)$, vascular permeability, and membrane stabilization. Thus, the present study validated the scientific rationale of ethnomedicinal use of $S$. robusta and unveils its mechanism of action [68]. Jyothi et al. have been reported the antinociceptive and anti-inflammatory activity of methanolic extract of leaves of $S$. robusta. The extract produced a dose-dependent inhibition of carrageenan-induced paw edema in rats. At the same doses, antinociceptive effect was also observed with hot plate devicemaintain that 550C, acetic acid induced writhing, formaline induced paw-liciking, tail clip and tail flick models in mice the result of the present study confirm the use of Shorea robusta traditionally for the treatment of pain full inflammatory conditions [69,70].

Wani et al. investigated the ethanolic SRE resin for analgesic activity by making use of different central and peripheral pain models. The extract produced significant central and peripheral analgesic effects as is evident from increase in reaction time in hot plate and tail flick tests, inhibition in writhing counts in acetic acid-induced writhing test, inhibition of licking time in formalin-induced hind paw licking, increased pain threshold in paw withdrawal latency in carrageenaninduced hyperalgesia, and increased paw withdrawal threshold in postsurgical pain [71]. Wani et al. also evaluated the antipyretic activity of $S$. robusta leaves using brewer's yeast-induced pyrexia in rats. Significant reduction in pyrexia was observed at all dose levels of $S$. robusta extract [72].

\section{Anti-obesity activity}

Supriya et al. have been reported the anti-obesity activity of S. robusta leaves extract using high-fat diet-induced obesity in albino rat's model. The leaves extract showed the significant effect in reduction of fat [73].

\section{Antihyperlipidemic and antidiabetic activity}

Sudha et al. investigated the anti-hyperlipidemic and antidiabetic activity of $S$. robusta leaves using alloxan-induced rat models. The result indicated that the significant reduction reduction in fat [74]. Ravichandiran et al. observed the biochemical parameters of S. robusta leaves in streptozotocin-induced diabetic rats. The ethanolic SRE leaves significantly prevented loss of body weight and reduce urine sugar. The results indicated that the ethanolic extract produced significant $(\mathrm{p}<0.001)$ in biochemical parameter [75] Kalaiselv et al. have been reported the preventive effect of $S$. robusta bark using diethyl nitrosamine-induced hepatocellular carcinoma in rats. The bark extract administered to rat models showed preventive effect [76]

\section{CONCLUSION}

Medicinal plants have been used for centuries as remedies for human diseases because they contain components of therapeutic value [77]. The use of botanical drugs as well as other alternative forms of medical treatment is enjoying great popularity in the late 1990's; most of botanicals are secondary metabolites, of which at least 12,000 have been isolated. In many cases, these substances served as plant defense mechanism against predation by microorganisms, insects, and herbivores [78-80]. S. robusta is an important Ayurvedic drug which has also been studied extensively by different investigators. Shorea robusta not only destroys pathogenic bacteria but also is used in wound healing, anti-inflammatory, analgesic, and antioxidant [81,82]. Different parts of $S$. robusta such as leaves, stem bark, and floral parts were used for the various pharmacological activities. It stimulates the antioxidant, antibacterial, and wound healing and anti-inflammatory activity due to the presence of polyphenols, flavonoids, and triterpenoids $[83,84]$. These compounds are believed to be responsible for the pharmacological activities of plant extract. The present review clarified the main active ingredients and pharmacological effects of $S$. robusta as a promising plant as a result of effectiveness and safety. Further studies should be carried out this plant to discover the unrevealed part of it which may serve for the welfare of humankind.

\section{AUTHOR'S CONTRIBUTIONS}

All three authors have equal contribution of read, manuscript compilation, and editing of this review manuscript.

\section{CONFLICTS OF INTEREST}

There are no conflicts of interest among authors of this publication.

\section{REFERENCES}

1. The Wealth of India. Raw Materials. Vol. X. New Delhi: CSIR. 1976. p. 175.

2. Croom EM. Documenting and evaluating herbal remedies. Econ Bot 1983;37:13-27.

3. The Ayurvedic Pharmacopoeia of India. Ministry of Health, Government of India. New Delhi: The Ayurvedic Pharmacopoeia of India; 2001.

4. Sharma PC, Yelne MB, Dennis TJ. Database on Medicinal Plants Used in Ayurveda. $3^{\text {rd }}$ ed. New Delhi. India: Central Council for Research in Ayurveda and Siddha; 2005. p. 282-4.

5. Chandel KP, Shukla G, Sharma N. Biodiversity in Medicinal and Aromatic Plants in India: Conservation and Utilization. New Delhi, India: National Bureau of Plant Genetic Resources; 1996.

6. Chitale VS, Behra MD. Can the distribution of Sal (Shorea robusta Gaertn.f.) shift in the northeastern direction in India due to changing climate? Curr Sci India 2012;102:1126-35

7. Patwardhan B, Warude D, Pushpangadan P, Bhatt N. Ayurveda and traditional Chinese medicine: A comparative overview. Evid Based Complement Alternat Med 2005;2:465-73.

8. Misra B, Vaisya R. Tailavarga in Bhavaprakasha nighantu. Part I, B, The Kashi Sanskrit Series. Varanasi, India: Chaukhumba Bharati Academy; 1963. p. 779.

9. Patwardhan B, Chopra A, Vaidya AD. Herbal remedies and the bias against Ayurveda. Curr Sci 2003;84:1165-6

10. Vaidya RA, Vaidya AD, Patwardhan B, Tillu G, Rao Y. Ayurvedic pharmacoepidemiology: A proposed new discipline. J Assoc Physicians India 2003;51:528

11. Bursal E, Gulçin I. Polyphenol contents and in vitro antioxidant activities of lyophilized aqueous extract of kiwifruit (Actinidia deliciosa). Food Res Int 2011;44:1482-9.

12. Morikawa T, Chaipech S, Matsuda H, Hamao M, Umeda Y, Sato H, et al. Antidiabetogenic oligostilbenoids and 3-ethyl-4-phenyl-3,4dihydroisocoumarins from the bark of Shorea roxburghii. Bioorg Med Chem 2012;20:832-40.

13. Evans WC. Trease and Evans Pharmacognosy. London: Harcourt Publisher Ltd.; 2002. p. 472-4.

14. Kokate CK, Purohit AP. Pharmacognosy. $38^{\text {th }}$ ed. Pune, India. Nirali Prakashan; 2005. p. 600-4.

15. Tondon N, Sharma GM. Quality Standards of Indian Medicinal Plants. New Delhi: Indian Council of Medical Research; 2003. p. 207-9.

16. Kar A. Pharmacognosy and Biotechnology. $2^{\text {nd }}$ ed. New Delhi. India: New Age International Private Ltd.; 2007.

17. Khare CP. Indian Medicinal Plants. An Illustrated Dictionary. New York: Springer International ed. 1989. p. 29.

18. Chunekar KC, Pandey GS. Bhavaprakasha Nighantu. Varanasi: Chaukhambha Bharati Academy; 2010. p. 508-9

19. Sastry JL. Dravyaguna Vijnana. Varanasi: Chaukhambha Orientalia; 
2005. p.78-6.

20. Yaseen Khan M, Ali SA, Pundarikakshudu K. Wound healing activity of extracts derived from Shorea robusta resin. Pharm Biol 2016;54:542-8.

21. Dunphy JE, Edwards LC, Udupa KN. Wound healing; A new perspective with particular reference to ascorbic acid deficiency. Ann Surg 1956;144:304-17.

22. Erhlich HP, Hunt TK. Effect of cortisone and anabolic steroids on tensile strength of healing wound. Ann Surg 1969;170:203-6.

23. Lowry OH, Rosebrough NJ, Farr AL, Randall RJ. Protein measurement with the Folin phenol reagent. J Biol Chem 1951;193:265-75.

24. Sahasrabudhe PB, Dhondge RD, Panse N. Raal ointment compared with $1 \%$ silver sulfadiazine cream for the treatment of second degree burns. Indian J Burns 2014;22:37-42.

25. Mukherjee H, Ojha D, Bharitkar YP, Ghosh S, Mondal S, Kaity S, et al. Evaluation of the wound healing activity of Shorea robusta, an Indian ethnomedicine, and its isolated constituent(s) in topical formulation. J Ethnopharmacol 2013;149:335-43.

26. Mukherjee PK, Mukherjee K, Rajesh Kumar M, Pal M, Saha BP. Evaluation of wound healing activity of some herbal formulations. Phytother Res 2003;17:265-8.

27. Nayak S, Nalabothu P, Sandiford S, Bhogadi V, Adogwa A. Evaluation of wound healing activity of Allamanda cathartica. L. And Laurus nobilis. L. Extracts on rats. BMC Complement Altern Med 2006;6:12.

28. Prasad V, Dorle AK. Evaluation of ghee based formulation for wound healing activity. J Ethnopharmacol 2006;107:38-47.

29. Wani TA, Chandrashekar HH, Kumar D, Prasad R. Wound healing activity of ethanolic extract of Shorea robusta gaertn F. Resin. Indian J Exp Boil 2012;50:277-81.

30. Wani TA, Chandrasekhara HH, Kumar D. Anti-inflammatory and antipyretic activities of the ethanolic extract of Shorea robusta Gaertn.f. Resin. Ind J Biochem Biophys 2012;49:963-7.

31. Datta HS, Mitra SK, Patwardhan B. Wound healing activity of topical application forms based on Ayurveda Hindawi publishing corporation. Evid Based Complementary Altern Med 2011;2011. Article ID: 134378, 10 Pages.

32. Chithra P, Sajithlal GB, Chandrakasan G. Influence of Aloe vera on collagen turnover in healing of dermal wounds in rats. Indian J Exp Biol 1998;36:896-901.

33. Nayak BS, Sandiford S, Maxwell A. Evaluation of the wound-healing activity of ethanolic extract of Morinda citrifolia L. Leaf. Evid Based Complementary Altern Med 2009;6:356-6.

34. Sumitra M, Manikandan P, Suguna L. Efficacy of Butea monosperma on dermal wound healing in rats. J Biochem Cell Biol 2005;37:566-73.

35. Hota RK, Bapuji M. Triterpenoids from the resin of Shorea robusta. Phytochemistry 1993;32:466-8

36. Sushma RK, Sreedhara RP, Nayak JP, Hemalatha B, Keerthana P, Kumar MB. Biomechanical, biochemical and histological evidences for wound healing properties of Indian traditional medicines. Int J Pharm Pharm Sci 2015;7:163-171.

37. Vashisht S, Singh MP, Chawla V. In-vitro antioxidant and antibacterial activity of methanolic extract of Shorea robusta Gaertn. F. resin. Int J Pharm Phytopharm Res 2016;6:68-71.

38. Banerjee RP, Banerjee S, Sarkar P, Pradhan NK. Phytochemical analysis and antimicrobial activity of natural resin (lal dhuna) from Shorea robusta (sal). Int J Pharm Sci Health Care 2014;4:52-60.

39. Adlakha MK, Bhargava AK, Kapoor R, Sharma LN, Singh C. Ayurvedic medicinal plant Shorea robusta (shala). Innov J Ayurvedic Sci 2014;18-21.

40. Murthy KS, Lakshmi N, Ramulu DR. Biological activity and phytochemical screening of the oleoresin of Shorea robusta Gaertn. F. Trop Subtrop Agroecosyst 2011;14:787-91.

41. Duddukuri GR, Rao DE, Kaladhar DS, Sastry N, Rao KK, Chaitanya KK, et al. Preliminary studies on in vitro antibacterial activity and phytochemical analysis of aqueous crude extract of Shorea robusta floral parts. Int J Curr Res 2011;3:21-3.

42. Smita HG, Chintamani UB. Study of antibacterial activity of resins of Boswellia serrata roxb ex colebr., commiphora mukul (hooks exstocks) engl., Gardenia resinifera roth. And Shorea robusta gaertn. Int J Pharm Pharm Sci 2016;8:29-31.

43. Abdallah EA, Khalid AS, Ibhrahim N. Antibacterial activity of oleogum resins of Commiphora molmol and Boswellia papyrifera against methicillin-resistant Staphlococcus aureus (MRSA). Sci Res Essay 2009;4:351-6

44. Mahadlek J, Phachamud T, Wessapun C. Antimicrobial studies of Sonneratia caseolaris using different agar diffusion method. Res J Pharm Biol Chem Sci 2012;3:404-310.

45. Rajendra CE, Kumar DH, Yeshoda SV, Nadaf MA, Hanumanthraju N.
Comparative evaluation of antimicrobial activities of methanolic extract of Curcuma longa and Boswellia serrata. Int J Res Pharm Chem 2013;3:534-6

46. Ishnava $\mathrm{KB}$, Mahida $\mathrm{YN}$, Mohan JS. In vitro assessments of antibacterial potential of Commiphora wightii (Arn.) Bhandari. Gum extract. J Pharmacogn Phytother 2010;2:91-6.

47. Vimala G, Gricilda Shoba F. A review on antiulcer activity of few Indian medicinal plants. Int J Microbiol 2014;2014:519590.

48. Muthu S, Anusuya N, Bhuvaneswari P. Antiulcerogenic effect of resin from Shorea robusta gaertn. F. On experimentally induced ulcer models. Int J Pharm Pharm Sci 2013;5:269-72.

49. Goel RK, Sairam K. Antiulcer drugs from indigenous sources with emphasis on Musa sapientum, Tamra bhasna, Asparagus racemosus and Zingiber officinale. Indian J Pharmacol 2002;34:100-10.

50. Hiruma-Lima CA, Gracioso JS, Bighetti EJ, Grassi-Kassisse DM, Nunes DS, Brito AR, et al. Effect of essential oil obtained from croton cajucara benth. On gastric ulcer healing and protective factors of the gastric mucosa. Phytomedicine 2002;9:523-9.

51. Kalra P, Sharma S, Suman, Kumar S. Antiulcer effect of the methanolic extract of Tamarindus indica seeds in different experimental models. J Pharm Bioall Sci 2011;3:236-41.

52. Andrikopoulos NK, Kaliora AC, Assimopolou NA, Papapeorgiou VP. Biological activity of some naturally occurring resins, gums and pigments against in vitro LDL oxidation. Phytother Res 2003;7:501-7.

53. Suzuki Y, Ishihara M, Segami T, Ito M. Anti-ulcer effects of antioxidants Quercetin alpha-tocopherol nifedipine and tetracycline in rats. Jpn J Pharmacol 1998;78:435-41.

54. Mathavi P, Nethaji S. In-vitro antioxidant activity of Shorea robusta leaf extract. Int J Res Biochem Biophys 2014;4:22-6.

55. Subramanian R, Subbramaniyan P, Raj V. Antioxidant activity of the stem bark of Shorea roxburghii and its silver reducing power. Springerplus 2013;2:28.

56. Amarowicz R, Pegg RB, Moghaddam PR, Barl B, Weil JA. Free radical-scavenging capacity and antioxidant activity of selected plant species from the Canadian prairies. Food Chem 2004;84:551-62.

57. Nikfardjam MS, Gy L, Dietrich H. Resveratrol-derivatives and ant oxidative capacity in wines made from botrytized grapes. Food Chem 2006;96:74-9

58. Rice-Evan CA, Miller N. Antioxidant property of phenolic compounds. Trends Plant Sci 1997;2:152-9.

59. Soares JR, Dinis TC, Cunha AP, Almeida LM. Antioxidant activities of some extracts of Thymus zygi. Free Rad Res 1997;26:469-78.

60. Sotheeswaran S, Pasupathy V. Distribution of resveratrol oligomers in plants. Phytochemistry 1993;32:1083-92.

61. Gokulakrishnan K. Bark extract of Shorea robusta on modulation of immune response in rats. Int J Recent Sci Res 2012;3:693-7.

62. Kanjwani DG, Marathe TP, Chiplunkar SV, Sathaye SS. Evaluation of immunomodulatory activity of methanolic extract of piper betel. Scand J Immunol 2008;67:589-93.

63. Kore KJ, Shete RV, Kabra MP, Rachhadiya RM, Attal AR. Immunomodulatory activity of Balanite roxburghi. J Pham Res Health Care 2011;3:63-7.

64. Lily G, Padwad Y, Singh R, Karan D, Chanda S, Chopra MK, et al. Anti-inflammatory activity of Seabuckthorn (Hippophae rhamnoides) leaves. Int Immunopharmacol 2005;5:1675-84.

65. Patwardhan B, Kalbag D, Patki PS, Nagsampagi BA. Search of immunomodulatory agents: A review. Indian Drugs 1990;28:348-58.

66. Summerfield A, Saalmüller A. Interleukin-2 dependent selective activation of porcine gamma delta $\mathrm{T}$ lymphocytes by an extract from the leaves of Acanthospermum hispidum. Int J Immunopharmacol 1998;20:85-98.

67. Nainwal P, Bhatt R, Nanda D, Saini P. Screening of in-vitro antiinflammatory activity of aqueos extract of leaves of Shorea robusta. Int J Pharmacol Screen Method 2013;3:43-5.

68. Chattopadhayay D. Inhibition of TNF- $\alpha$ and Inos expression by Shorea robusta L: An ethnomedicine used for anti-inflammatory and analgesic activity. Evid Based Complement Altern Med 2012;2012. Article ID: 129152, 14 Pages

69. Jyothi G, Carrey WM, Krishna MG. Antinociceptive and antiinflammatory activity of methanolic extract of leaves of Shorea robusta. Pharmacologyonline 2008;1:9-19.

70. Jyothi G. Antinociceptive and anti-inflammatory activity of methanolic extract of leaves of Shorea robusta. Pharmacologyonline 2008;1:11-2.

71. Wani TA, Chandrashekhara HH, Kumar D. Analgesic activity of ethanolic extract of Shorea robusta resin in experimental animals. Indian J Pharmacol 2012;44:493-9.

72. Wani TA, Chandrashekara HH, Kumar D, Prasad R, Sardar KK, 
Kumar D, et al. Anti-inflammatory and antipyretic activities of the ethanolic extract of Shorea robusta gaertn. F. Resin. Indian J Biochem Biophys 2012;49:463-7.

73. Supriya K. Antiobesity activity of Shorea robusta G. Leaves extract on high fat diet induced obesity in albino rats Res. J Pharm Biochem Sci 2012;3:542-54.

74. Sudha S, Prasanna G. Antidiabetic and antihyperlipidemic effect of ethanolic extract of Shorea robusta gaertn.F. In alloxan induced rats. J Med Toxicol 2013;7:67-72.

75. Ravichandiran V, Satish PV, Yadav BV. Attenuation of biochemical parameters of Shorea robusta leaves in streptozotocin induced diabetic rats. World J Pharm Res 2015;4:1662-72.

76. Kalaiselvan A, Gokulkrishan K. Bark extract of Shorea robusta on modulation of immune response in rats. Int $\mathrm{J}$ Recent Sci Res 2012;3:693-7.

77. Hobbs C. Valerian monograph. Herb Gram 1989;21:19-34.
78. Grieve M. In: Leyel CF, editor. A Modern Herbal. London: Tiger Books International; 1976. p. 912.

79. Benigni R, Capra C, Cattorini P. Piante Medicinali Chimica Farmacologia E Terapia. Vol. 1. Milano: Inverni \& Della Beffa; 1971. p. 730

80. Ellingwood F, Lloyd JU. A Systematic Treatise on Materia Medica and Therapeutics. Chicago: Chicago Med Press; 1900. p. 706.

81. Scudder JM. Specific Medications and Specific Medicines. $15^{\text {th }}$ ed. Cincinnati: Scudder Bros; 1903, 1985. p. 432

82. Fleming T. PDR or Herbal Medicines. Montvale, NJ: Medical Economics Company, Inc.; 1998.

83. Newall CA, Anderson LA, Phillipson JD. Herbal Medicines: A Guide for Health-Care Professionals. London: The Pharmaceutical Press; 1996.

84. Peralta CM, Henestrosa C, Gil RA, Fernández LP, Acosta G. Novel spectrofluorimetric method for boldine alkaloid determination in herbal drugs and phytopharmaceuticals. Spectrochim Acta A Mol Biomol Spectrosc 2017;184:101-8. 